\title{
THE ERROR ANALYSIS OF INTERLINGUAL AND INTRALINGUAL INTERFERENCES OF THE STUDENTS: A CASE STUDY OF TOURISM STUDY PROGRAM
}

\author{
Putu Pande Novita Sari' ${ }^{1}$ I Gede Budasi², Ni Luh Putu Sri Adnyani ${ }^{3,}$ \\ Ni Komang Arie Suwastini ${ }^{4}$ \\ 1,2,3,4Universitas Pendidikan Ganesha \\ 1,2,3,4Singaraja, Bali, Indonesia \\ Email: pandeputunovitasari@gmail.com¹, gede.budasi@undiksha.ac.id², \\ niluhputusriadnyani@gmail.com³, arie.suwastini@undiksha.ac.id ${ }^{4}$
}

\begin{abstract}
:
This study aimed to analyze the students' interlingual and intralingual interferences of Tourism Study Program at a State University in North Bali. A qualitative approach was applied by examining the students' final projects of English writing for the academic year 2020/2021. In this case study, 15 final projects were chosen using the purposive sampling technique. Data collection was done through reading, notetaking, classifying, and describing. The findings revealed that the most frequent interlingual form produced by the students was using Indonesian Syntax Pattern, while the intralingual form was the simplifications. Therefore, interlingual and intralingual interferences were found in the students' final project. There are two implications of this study, i.e. (i) teachers need to enhance their pedagogy for the teaching and learning sessions, particularly English grammar, (ii) students should learn more the English grammatical rules, which they can access many sources to learn English through watching a movie, listening to songs, talking with native speakers, reading novels and magazines.
\end{abstract}

\begin{abstract}
Abstrak:
Penelitian ini bertujuan untuk menganalisis interlingual dan intralingual mahasiswa Program Studi Pariwisata di salah satu Universitas Negeri di Bali Utara. Pendekatan kualitatif digunakan dalam penelitian ini dengan menguji tugas akhir siswa dalam penulisan bahasa Inggris pada tahun ajaran 2020/2021. Dalam studi kasus ini, dipilih 15 tugas akhir dengan teknik purposive sampling. Pengumpulan data dilakukan melalui membaca, mencatat, mengklasifikasi, dan mendeskripsikan. Hasil temuan mengungkapkan bentuk interlingual yang paling sering dihasilkan oleh siswa adalah menggunakan Pola Sintaks Bahasa Indonesia sedangkan bentuk intralingualnya adalah penyederhanaan. Dengan dimikian, terdapat error interlingual dan intralingual dalam tugas akhir mahasiswa. Ada dua implikasi dari penelitian ini, yaitu (i) pengajar perlu meningkatkan pedagogi mereka untuk proses belajar mengajar khususnya tata bahasa Inggris, (ii) pembelajar harus mempelajari lebih lanjut aturan tata bahasa Inggris. Mereka dapat mengakses banyak sumber untuk belajar bahasa Inggris seperti menonton film, mendengarkan lagu, berbicara dengan penutur asli, membaca novel maupun majalah.
\end{abstract}

\section{Keywords:}

Interlingual, Intralingual, Interference, EFL Learners

How to Cite: Sari, P. P. N., Budasi, I. G., Adnyani, N. L. P. S., \& Suwastini, N. K. A. (2021). The Error Analysis of Interlingual and Intralingual Interferences of the Students: a Case Study of Tourism Study Program. Lentera Pendidikan : Jurnal Ilmu Tarbiyah dan Keguruan, 24(1), 69-81. https://doi.org/10.24252/lp.2021v24n1i7. 


\section{INTRODUCTION}

In foreign language learning, writing is often assumed as the most challenging skill to acquire compared to other skills such as listening, speaking, and reading. Writing requires a cognitive process that includes thinking ability and verbal command (Murtiana, 2019). Foreign language learners have to consider multiple writing aspects to generate and express ideas using the correct forms of the target language, such as vocabulary, syntax, cohesive devices, and writing mechanics (Murtiana, 2019). Writing is the most challenging language teaching skill, neither in the mother tongue nor in a foreign language (Al-Halawani, 2018). Generally, writing in English is a complex process for a foreign language learner. It is not surprising that interlingual and intralingual writings are indivertible sections of EFL students. Ellis (1997) noted that fossilization of students' structure does not occur in native language acquisition but is typical in target language acquisition.

Many interlingual and intralingual forms are made when students write or translate into foreign languages (Al-Halawani, 2018). These forms break the established rules of English structure and thus are regarded as incorrect. It has been widely claimed that the learners use their native language structure in composing the English sentence. Hence, it produces error sentences in English. Since interlanguage increases in EFL teaching, making errors are commonly happened both in oral and written text. Many sides lead the students of English as a foreign language to make interlingual and intralingual forms. Brown (1980) said that the students' interlanguage in the target language result from students' assumptions. The target language forms are identical to the native language (interlingual). Another is the negative transfer of items within the target language called intralingual errors.

The fossilizations contain phonological, morphological, and syntactic features in the speech of native language speakers that differs from the target language rules. According to Manzolim \& Gumpal (2015), errors occur because their first language (L1) interference affected their English grammar constructions. Errors can help the students be more aware of their confusion, which shows they go through a developmental process (Kill, 2003). Therefore, students' composition errors still exist even though they have learned English as a foreign language since they were in the fourth grade of Elementary School. Research results confirmed that senior high school EFL students, Vocational High School, Fresh Graduate, and Postgraduate still made errors in their composition. The errors are caused by the confusion when they have to change the pattern from the first language, which already stays in their brain, to the target language pattern (Cheng, 2015; Fauziati, 2017; Asikin, 2017; Handayani, Ihsan, \& Mirizon, 2019).

Foreign language learners experience interlanguage almost at all levels of education, including college students. Proficiency in various foreign languages is the fundamental prerequisite for successful communication, for example, in the tourism industry. Similarly, mutual benefits understanding among students involved in several exchange programs universities. Intercultural contacts contribute to the development of 
intercultural communication. Therefore, it is necessary to increase awareness of the importance of foreign language skills and foster language development in the tourism and hospitality industry (Sindik, 2013). In addition, Adnyani (2011) agreed that one of the crucial aspects of cross-cultural communication's success is cultural differences. One of the essential skills in the tourism industry is the ability to write English text. Therefore, the students' composition errors should be avoided.

Fauziati (2017) studied interlanguage, that was, permeability. She found that there were 264 error-formed sentences elicited from English free compositions. This study showed that interlanguage was influenced by the native and target languages in lexical and syntactic levels. Native language influences vocabulary (Indonesian borrowings), and the target language influence was on grammar (verb tenses). Darussalam (2013) studied learning strategies used by students, which result in interlingual errors. He revealed that the learners produced 317 error-formed sentences. Wrong learning strategies caused those forms by the learners. The factors that influenced the errors were $43.53 \%$ overgeneralization of the target language, $41.01 \%$ of the first language transfer, and $15.46 \%$ of the oversimplified. Asikin (2017) studied the analysis of interlanguage produced by third-grade high school students in narrative text. This study revealed that the students' interlingual production was in the form of a passive sentence, choosing incorrect verb agreement, choosing the wrong auxiliary, making the unparalleled sentence, and translating sentence word by word. Thus, the errors produced by EFL learners due to the processing of learning or acquiring a target language (Al-Khresheh, 2015).

Tiarina (2017) studied interlanguage performed by students of the English literature study program. The subjects of the study were 20 English Literature students. The data of students' errors were in the form of guided writing (recount text). The study revealed 15 aspects of grammar errors experienced by the students. Nurhayati (2015) studied the grammatical errors and the interlanguage of students' writing in recount text. The study showed four types of student error: omission in all of the grammatical features' aspects, addition in all aspects of the grammatical feature, misinformation of all aspects of the grammatical feature, and disordering of all aspects of the grammatical feature.

The previous studies reviewed during this study have investigated erroneous students' composition of EFL learners in junior high school, Senior High School, Fresh Graduate, and Postgraduate. Meanwhile, none of these studies investigated the English for Tourism Study Program students' final project. The students had studied English at the college for three years. Besides, it is also supported by their experience in the tourism industry. Thus, it is expected that the students for tourism are capable of applying English grammar. Based on the preliminary analysis of the students' final projects in the academic year 2020/2021, the students committed various interlingual forms, including the omission of plural marker $-\mathrm{s}$ and incorrect prepositions, while the intra-language forms were on students' verb tenses. Thus, this study was conducted since it could become a formative evaluation for teachers or lecturers to teach English as a foreign 
language. Analyzing the learners' errors was a pivotal part of language teaching and learning. It helped the teacher diagnose learners' problems in constructing utterances or sentences, thus finding a way to provide feedback. It was one of the reasons why this study worth conducting. Therefore, this study focused on the errors of students' interlingual and intralingual interferences. This study was a case study conducted in the Tourism Study Program at a State University in North Bali.

\section{RESEARCH METHOD}

This research used the qualitative descriptive method. The instrument was the tourism program's final project of the students who learned English academic $2020 / 2021$. The final projects were chosen as the object using the purposive sampling technique, which fulfilled two criteria: high achieving students and the final project published in the academic year 2020/2021. There were 15 final projects analyzed in this study.

Data were collected through four steps, namely reading, note-taking, classifying, and describing. The first step was reading to gather the students' interlingual and intralingual forms in their final project. Note-taking was also used to find the interlanguage and intra-language of students' final project. The researcher classified the interlanguage and intra-language interferences after they were discovered. Data analysis was done during the whole process of the data collection procedure. This process was repeated to ensure the validity of the data.

Data analysis adapted the research model from Miles, Huberman \& Saldana (2014). Qualitative data analysis would be done simultaneously with data collection, data display, condensation, and conclusion drawing/verification. In other words, data analysis happened at every step of the research. Once the data are collected, an analysis must be taken before categorizing them. During the analysis, the process of data condensation and conclusion drawing also happened simultaneously. Thus, the analysis was done repeatedly until the analysis is saturated.

\section{RESULTS AND DISCUSSION}

The results of the analysis were divided into two, i.e., interlingual and intralingual interferences. The narrative description as the following:

\section{Interlingual Interference}

This study indicated that the students' interlingual system was interfered with by their native language. They tried using Indonesian terms in composing the English sentence. The types of interlingual forms that the students produced were: the use of Indonesian syntax pattern, Indonesian cognate, subject deletion, TO BE deletion, verb tense, the omission of plural sign (-s), omission of article, conjunction, word order, meaning not clear, unparalleled sentence, and wrong spelling. 
One of the interlingual forms found in the students' final project is the Indonesian syntactic pattern. The following were the students' final project examples:

(1) After done orientation.

Setelah orientasi selesai.

'After the orientation has been completed.'

(2) Bellboy activity is very heavy.

Tugas bellboy sangat berat.

'Being a bellboy is not easy.'

(3) The waiter feel nervous communication with guest.

Pelayan merasa gugup ketika berkomunikasi dengan tamu.

'The waiter feels nervous when communicating with the guest'.

The students used the Indonesian syntactic pattern in composing the English sentence in examples (1) to (3). From the first sentence, it is a translation of Indonesian which says 'Setelah orientasi selesai'. The students could say in proper English, 'After the orientation has been completed.' The second was 'Bellboy activity is very heavy.' It should be 'Being a Bellboy is not easy.' The word 'heavy' was suitable for indicating the weight of people and animals. This collocation was not matching to the object. The student tried to connect the job responsibility by using the word 'heavy'. The students did use English to compose the sentences; however, the pattern they used was an Indonesian grammar pattern which was unacceptable in English. Indonesian collocations referred to the direct translation of two or more words from the native language (Indonesian/Bahasa) to the target language (English) that follows the native language system, which goes along and acceptable to Indonesian as the native speaker (Suwastini, Wiraningsih, \& Adnyani 2020). When switching from English to Bahasa, the students have used Indonesian words' complete replacement (Tarone, 1994). The next interlingual forms found in students' final project were Indonesian cognates, as shown in examples (4) to (6).

(4) Marriot Bonvoy has similar operasional.

Mariot Bonvoy memiliki operasional yang sama.

'Mariot Bonvoy has similar operational.'

(5) Giving information servis to the guest

Memberikan pelayanan informasi kepada tamu

'Giving information service to the guest'.

(6) Explaining the facilitis about hotel.

Menjelaskan tentang fasilitas hotel.

'Explaining the facilities of the hotel.'

The students used Indonesian cognate in their writing, such as 'operasional' should be 'operational', 'servis' meant 'service', and 'fasilitis' should be 'facilities' in examples (4) to (6). The students believed that these words were similar between Indonesian-English in terms of form and meaning.

Subject deletion is another native language influence on the students' interlanguage. A complete English sentence should consist of a subject and a predicate, 
and it cannot be said as a complete sentence if the speakers' pattern does not consist of a subject (Kusumawardani \& Adnyani, 2020). The following were examples of students' utterances in which they omitted subjects in their sentences.

(7) 6 language functions and expressions used in Kartika Plaza Hotel.

(8) Always use the procedure in handling guest check-in.

(9) Also responsible in managing hotel's inventory such as rental items.

The students omitted the subject in English sentences in the examples (7) to (9). It was because the sentences begin with 'also and always'. They were categorized as an adverb, while in English, sentence adverb could not be a subject. In Indonesian colloquial, subject deletion was very common (Adnyani, Beratha, Pastika, \& Suparwa, 2018; Sugono, 1991).

The following interlingual forms found in the students' final project were TO BE deletion, as shown in examples (10) to (12).

(10) What challenges faced when handling complaints?

Tantangan apa saja yang ditemukan saat menanggani keluhan tamu?

'What are the challenges faced when handling complaints?

(11) There some SOP at Sheraton.

Ada beberapa SOP di Sheraton.

'There is some SOP at Sheraton'.

(12) They responsible to make drink.

Mereka bertanggung jawab membuat minuman.

'They are responsible for making a drink.'

The students were influenced by their non-existence in examples (10) to (12). T0 $\mathrm{BE}$ is the most crucial verb in English. It is used as a main verb, an auxiliary, as well as in the passive voice. TO BE always changes form following the subjects and the tense. Verb tenses are another interlingual form. Examples (13) to (15) show verb tense in the students' final project.

(13) Can be understand by guest.

Dapat dimengerti oleh tamu.

'Can be understood by the guest.'

(14) Several strategies that must be take in handle guest.

Ada beberapa strategi yang digunakan ketika menanggani tamu.

'Several strategies that must be taken in handling guest.

(15) The data was obtain from interview.

Data diperoleh melalui wawancara.

'The data were taken from the interview'.

The students applied to the infinitive verb in their final project, such as 'understand' and 'obtain' in examples (13) to (15). The research of their final project was done, in which the students were required to report their final project using the simple past tense. Therefore, the students needed to change the verbs to 'understood' and 'obtained'. In Bahasa, time is only marked by an adverb of time, while the same verb form 
is used regardless of whether the event happens in the past, present, or future (Bahar et al., 2019). Pratiwi, Adnyani, and Putra (2020) stated that some possibilities caused the verb tenses error in the students' interlingual production.

The following interlingual form found in the students' final project was the omission of plural sign (-s). The students omitted the plural sign 's' due to the lack of awareness of the rules in English structure since plurality did not mark by 's' in their native language (Bahasa) (Suwastini, Wiraningsih, \& Adnyani 2020). The examples (16) to (18) were as follows.

(16) Ensuring all stationary and equipment working properly.

'Ensuring all stationaries and equipment working properly.'

(17) There were several language expression.

'There were several language expressions'.

(18) There are ten employee in W Hotel \& Spa.

'There are ten employees at W Hotel \& Spa.

The students made some incorrect utterances syntactically in examples (16) to (18). It can be seen from the use of words showing the students missed putting the 's/es' after the word. The words such as 'stationary', 'expression', 'staff' should be added by a plural marker such as 'stationaries', 'expressions', and 'employees.' This error happened because their first language did not have suffix 's' as a plural marker (Manik \& Suwastini, 2020). Bahasa has no rules about plurality as English has, which after preceding by the plural determiner, the word should be added by plural mark such as 's/es'.

Other interlingual forms found in students' final projects have omitted an article, as shown in examples (19) to (21).

(19) Restaurant is * place that could visited by everyone.

Rumah makan adalah tempat yang bisa dikunjungi semua orang.

'Restaurant is a place that could be visited by everyone.

(20) The following is * conversation between * waiter and waitress.

Berikut adalah sebuah percakapan antara pelayan laki-laki dan perempuan.

'The following is a conversation between a waiter and a waitress.'

(21) Cashier is * section that has responsibility in payment method.

Kasir adalah bagian yang bertanggung jawab dalam metode pembayaran.

'Cashier is a section that has responsibility in payment method.'

In English, whenever an article was followed by a word that began with vocal sounds, then the article used must be 'an'. If it was followed by a word that begins with consonant sounds, the article must be ' $a$ '. If a specific entity has been mentioned before, the article of the noun 'the'.

Interlingual forms produced by students were also available in the use of incorrect conjunction.

(22) And the next thing is when we run out of luggage tags.

Dan hal berikutnya adalah ketika kita kehabisan label koper.

'The next thing is when we run out of luggage tags.'

Informing about distances and locations and availabilities. 
tentang jarak, lokasi, dan ketersediaan.

'Informing about distances, locations, and availabilities.'

(24) And the writer found several types of language functions.

Dan penulis menemukan beberapa tipe-tipe fungsi bahasa.

'The writer found several types of language functions.'

Examples (22) and (24) indicated that the students still used the Indonesian structure to put the conjunction in front of the sentence. Meanwhile, the conjunction should connect two sentences. Hence, their understandings of using conjunction were less. Example (23) showed the students who tried to connect two sentences that did not relate to each other. They thought that the use of the conjunction was accepted in that way.

The next interlingual forms found in the students' final project were word order, as shown in examples (25) to (28).

(25) To analyse obtain data.

Untuk menganalisis data yang diperoleh.

'In analyzing the data.'

(26) The writer used note to take a note the data of research.

Penulis menggunakan catatan untuk mencatat data penelitian.

'The writer used note-taking in collecting data on the research'.

(27) Source of data is brochure.

Sumber data berasal dari brosur.

'The source of data was taken from the brochure.'

Example (25) to (27) indicated that the students made some incorrect word order. It can be seen in example (25) 'To analyse obtain data' was incorrect word order. It should be 'In analysing the data.' Example (27) 'the writer used note to note the data of research' it should be 'the writer used note-taking in collecting the data of the research.' According to Biber (1991), the term of order refers to the elements of a clause. Therefore, word order was the placement of the core elements or the clause in a sentence. Another interlingual form is unclear meaning, as can be seen in examples (28) to (30).

(28) Here is some language expressions used.

Berikut adalah ekpresi bahasa yang digunakan.

'The following are examples of language expressions.'

(29) After writer analysing the brochure.

Setelah penulis menganalisis brosur.

'After the writer has analyzed the brochure.'

(30) FO is divided into more section and more duty.

FO dibagi menjadi beberapa bagian dan tugas.

'FO is divided into several sections and duties.'

Unclear meaning happened when a sentence or utterance is ambiguous, as seen in the example (30) 'FO department is divided into more section and more duties.' This 
sentence was not clear. It would be better if changed into 'Front office department is divided into several sections and responsibilities.'

Another interlanguage found in students' final project was unparalleled structure. Some examples could be seen in example (31) to (33).

(31) The steps in handling the guests are greeting, welcoming and offers assistance.

(offering)

(32) Informing any possible charge, ensure the process of collecting luggage, reconfirm to the guest. (ensuring, reconfirming).

(33) Many parties are supporting and contribute. (contributing).

Using parallelism structure in writing helped the reader and writer avoid redundancy. Besides, it also made the sentence clear and equal (Asikin, 2017). Parallelism was intended to make the readers satisfied.

The wrong spelling of the interlingual form was found in the students' final project as follows:

(34) Interview that used to profesional purposes. (professional)

(35) Thanks to my friend for your kidness (kindness).

(36) PMS is the sistem that helps the operational (system).

The students sometimes wrote English words in the wrong spelling. For example: sistem, profesional, and kidness. The students wrote those words because they were lack of vocabulary and spellings of English words.

\section{Intralingual Interference}

This study showed that the students' intralingual system was interfered with by their native language. They had tried using Indonesian terms in composing English sentences. The types of intralingual forms that the students have produced were: overgeneralisation of past form -ed, false friend (similar in meaning), simplifications, induced errors, the addition of the article, addition TO, the use of incorrect TO BE, and over-generalisation of TO BE. The first intralingual forms were over generalizations of past form -ed. Kusumawardani \& Adnyani (2020) confirmed that the cause of overgeneralizations was the students knew that they should add -ed at the end of the verbs indicating past events.

(37) In order to developed human resources in the hotel.

(38) It is important to used proper language expressions in job interviews.

(39) Staff in Marriott Bali Kuta who had welcomed me very well.

In examples (37) to (39), the students failed to notice that the infinitive verb in English did not require the ending. Besides, it was found that the students also used similar words (false friend) in a sentence. False friends are the pairs of words or phrases in two languages that look similar but differ significantly in meaning.

(40) They are still many beneficial benefits for the membership.

(41) Greeting could make the guest feel relax and enjoy in overcame the problem.

In example (40), beneficial and benefits are similar to the same meaning, which refers to profit or advantage. 
Other intralingual forms were simplifications. Again, simplification was a result of the students producing simple linguistic forms.

(42) Job description they can't do. (cannot)

(43) We're searching for receptionist position. (we are)

(44) It is important to use proper language expression. (it is)

Corder (1981) mentioned that learners did not have a complex system that they could simplify. This kind of error was committed by omission and several linguistic elements at the level of either spelling or grammar. The following intralingual forms were induced error.

(45) There are several languages expressions are used of handling the guest. (in)

(46) There are several departments in U Pasha Seminyak Hotel. (at)

The students were incorrect in applying appropriate prepositions in examples (45) to (46). Fauziati (2011) found that their target language development mostly influenced the students' intralingual. Meanwhile, article addition was also found in students' final projects.

(47) Greeting is the first step before asking for an identity.

(48) The front office is the primary section when serving guests.

(49) This study was based on the writer's notes during the on the job training.

In examples (47) to (49), the students were overgeneralizing the use of articles.

The possible cause was the lack of students' understanding of the article's use in composing English sentences (Pratiwi, Adnyani \& Putra, 2020). Since native language and target language different concepts for the prepositional system, the students faced difficulties in applying the appropriate preposition while learning the target language (Suwastini, Wiraningsih, \& Adnyani 2020). It became problematic because, compared Bahasa, English has numerous prepositions. For example, the Indonesian preposition di, which designates place and time, has several English correspondences, such as 'in', 'on', 'at' (Bahar, Husai, \& Aprianto, 2019).

Another intralingual error was the addition of 'TO' as follows:

(50) The writer decided to identified types of letters.

(51) Customers satisfied to maximised the benefit of the product.

(52) This challenges to increased knowledge about vocabulary and grammar.

The example of intralingual in addition TO (verb agreement) in example (50) 'the writer decided to identified types of letters'. The problem arose when the student chose 'identified' instead of 'identify' after the preposition 'to'. The agreement 'to' should be followed by a bare infinitive. In this example, the student perhaps wanted to be consistent that he/she should use past tense. In addition, another intralingual error was the use of incorrect TO BE as follows:

(53) There is several language expressions used. (are)

(54) The purposes of this study is. (are)

(55) There was two procedure which not implemented by the interviewer. (were two procedures). 
Examples (53) to (55) showed that the students misused TO BE. The examples (53) to (55) should use to be 'are' because the sentences are plural form. The last intralingual form was the over-generalization of TO BE.

(56) This research was needed two instruments.

'This research needed two instruments'

(57) Food and Beverage who is take care with food.

'Food and Beverage Department is responsible for the needs of food.'

(58) The guest are can enjoy their drink while watch a sunset.

'The guest can enjoy their drinks while watching a sunset.'

Example (56) to (58), the students tended to overgeneralize the use of TO BE. It showed that the sentences were incorrect syntactically. It could be seen that students used 'to be' to compose a sentence, although they had to use a content verb in composing English sentences.

This study corresponded to the previous research, which indicated that the students' interlanguage and intra-language influenced their compositions. Murtiana (2019) agreed that interlingual errors were caused by native language interference. This study revealed that interlingual errors were in the forms of lexical and syntactical areas. The lexical selection appeared to be highly affected by the first language.

Other studies that revealed the interlanguage and intra-language production influence were conducted by Fauziati (2017). She reported that the students' interlingual production influenced both lexical and syntactic levels. The dominant native language influence was on vocabulary (i.e., Indonesian borrowings), and the target language influence was on grammar (i.e., verb tenses). Since the research subjects were vocational college students, their English level must have been enhanced enough not to interfere with the NL and TL lexical aspects in their interlingual production (Pratiwi, Adnyani, Putra, 2020). The students might either lack vocabulary repertoire or did not know the correct choice of words to use.

\section{CONCLUSION}

This study revealed that both interlingual and intralingual forms were found in the students' final project. Several interlingual forms: Indonesian syntax pattern, Indonesian cognate, subject deletion, verb tense marker, the omission of plural sign (-s), omission of article, incorrect conjunction, and word order meaning not clear, unparalleled structure, and wrong spelling. The most frequent interlingual form produced by the students was using Indonesian Syntax Pattern. The use of Indonesian structure in composing English sentences could infer that when there was a gap in the student's knowledge in the target language, they tended to borrow their native language words and structure to fill in English gaps. Meanwhile, the intralingual forms found in students' final projects were overgeneralisation of the past form (-ed), false friend (similar in meaning), simplifications, induced errors, the addition of an article, the addition of TO, the use of incorrect TO BE, and over-generalization of TO BE. The most frequent intralingual forms 
were simplifications. The students often made error-forms of the subjects, such as using TO BE in the sentences, forgot to change the tenses used because they had not been familiar with English structures.

Several implications could be drawn from the result of this study. Firstly, teachers need to make various kinds of teaching strategies to teach English grammar. Secondly, it is suggested that students learn more about English grammatical rules. Finally, students can access so many sources to learn English, such as watching a movie, listening to a song, talking with a native speaker, reading a novel, magazine, and internet.

\section{REFERENCES}

Adnyani, N. L. P. S. (2011). Introducting Target Language Culture through Movie Watching and Discussion. Jurnal Pendidikan Dan Pengajaran, 44(1), 77-83. https://doi.org/10.23887/jppundiksha.v44i1.141.

Adnyani, N. L. P. S., Beratha, N. L. S., Wayan Pastika, I., \& Nyoman Suparwa, I. (2018). The development of verbal morphology and word order in an Indonesian-German bilingual child: A case study. Topics in Linguistics, 19(1), 33-53. https://doi.org/10.2478/topling-2018-0003.

Adnyani, N. L. P. S., \& Kusumawardani, D. A. N. (2020). Interlanguage Analysis on Speech Produced by EFL Learners. Retorika: Jurnal Ilmu Bahasa, 6(2), 178-185. https://doi.org/10.22225/jr.6.2.1727.178-185.

Al-Khresheh, M. H. (2015). A review study of interlanguage theory. International Journal of Applied Linguistics and English Literature, 4(3), 123-131. https://doi.org/10.7575/aiac.ijalel.v.4n.3p.123.

Asikin, N. A. (2017). The Analysis of Interlanguage Produced By 3Rd Grade High School Students in Narrative Writing Text. Indonesian EFL Journal, 3(1), 39. https://doi.org/10.25134/ieflj.v3i1.652.

Bahar, B., Husain, D., \& Aprianto, E. (2019). The Indonesian syntactic structure interfere into English sentences: An interlanguage study. Budapest International Research and Critics in Linguistics and Education (BirLE) Journal, 2(4), 106-110. https://doi.org/10.33258/birle.v2i4.496.

Biber, H. D. (1991). Variation Across Speech and Writing. Inggris: Cambridge University Press.

Cheng, X. (2015). Interlanguage-based Error Analysis in Higher Vocational and Technological College EFL Education in China. Journal of Language Teaching and Research, 6(3), 639-646. https://doi.org/10.17507/JLTR.0603.22.

Corder, S. P. (1981). Error Analysis and Interlanguage. Inggris: Oxford University Press.

Darussalam, H. (2013). Learning strategy and interlanguage errors: a case study of Indonesian students learning english as a foreign language. Linguistik Dan Sastra, 25(1), 82-91. https://doi.org/10.23917/kls.v25i1.87.

Ellis, R. (1997). SLA research and language teaching. Inggris: Oxford University Press.

Fauziati, E. (2011). Interlanguage and error fossilisation: A study of Indonesian students learning English as a foreign language. Indonesian Journal of Applied Linguistics, 


\section{1(1), 25-40. https://doi.org/10.17509/ijal.v1i1.97.}

Fauziati, E. (2017). Native and target language influence on the students' interlanguage productions a case of Indonesian EFL compositions. Indonesian Journal of Applied Linguistics, 7(1), 54-63. https://doi.org/10.17509/ijal.v7i1.6858.

Handayani, R., Ihsan, D., \& Mirizon, S. (2019). Interlanguage Analysis of Syntactic and Diction Errors Found In Theses Written By Magister Students. Internasional of Indonesian Educaton and Teaching, 3(1). https://ejournal.usd.ac.id/index.php/IJIET/article/view/1713/1336.

Kill, I. (2003). Interlanguage Development of Five Korean English Learners. USA: Community College of Baltimore Education Ltd.

Manik, N. P. I. M. C., \& Arie Suwastini, N. K. (2020). Analyzing Grammatical Error in Students' Recount Text Writing in Junior High School. Humanis, 24(3), 238-246. https://doi.org/10.24843/jh.2020.v24.i03.p02.

Manzolim, A. ., \& Gumpal, B. (2015). Isabella State University rural campus written compositions: An Error Analysis. The Countryside Development Research Journal, 3(1), 64-75. https://cdrj.ssu.edu.ph/index.php/CDRJ/article/view/68.

Miles, B., Matthew, Huberman, Michael, A., \& Saldana, J. (2014). Qualitative Data Analysis. Sydney: Addison Wesley Longmen, Inc.

Murtiana, R. (2019). An Analysis of Interlingual and Intralingual Errors in EFL Learners' Composition. Journal of Education Studies, 4(2), 204. http://dx.doi.org/10.30983/educative.v4i2.2544.

Nurhayati, I. (2015). Interlanguage: Grammatical Errors on Students' Recount Texts (A Case Study of First Year of MAN 2 Banjarnegara in the Academic Year 2014/2015). ELT Forum: Journal of English Language Teaching, 4(1), 1-6. https://doi.org/10.15294/elt.v4i1.7918.

Pratiwi, P. D., Adnyani, N. L. P. S., \& Putra, I. N. A. J. (2020). Native and Target Language Influence on Students ' Interlanguage Speech. Linguistika, 27(2), 109-122. https://doi.org/10.17509/ijal.v7i1.6858.

Sindik, J. (2013). Importance of Foreign Languages for A Career in Tourism as Perceived by Students in Different Years of Study. Vitez-Tuzla-Zagreb-Beograd-Bucharest, 15(31). https://core.ac.uk/reader/16753420.

Sugono, D. (1991). Pelesapan subjek dalam bahasa Indonesia. Jakarta: Fakultas Pascasarjana Universitas Indonesia.

Suwastini, Ni Komang Arie, Adnyani, Ni Luh Putu Sri, Wiraningsih, P. (2020). An Analysis of Interlanguage among EFL Students' Speech Production in English Microteaching Class. The Asian EFL Journal, 27(4.5), 66-89. https://doi.org/10.1111/fcre.12520.

Tarone, E. (1994). Interlanguage. In K. Brown (Eds.), Encyclopedia of language and linguistics. New York: Elsevier.

Tiarina, Y. (2017). An Interlangauge Error Analysis: A Formative Evaluation For Freshmen. Lingua Didaktika, 11(2), 157-170. https://doi.org/10.24036/ld. 